\title{
DNA breakdown by the 4-quinolones and its significance
}

\author{
C. S. LEWIN* and J.T. SMITH†
}

\begin{abstract}
Microbiology Section, Department of Pharmaceutics, School of Pharmacy, 29-39 Brunswick Square, London WC1N 1AX
\end{abstract}

\begin{abstract}
Summary. DNA breakdown occurred in Escherichia coli KL16 exposed to nalidixic acid, ciprofloxacin or norfloxacin. However DNA breakdown does not seem to be the cause of the lethality of the 4-quinolones because it still occurred under conditions which abolished the lethality of nalidixic acid. Furthermore, no correlation was found between the amount of DNA breakdown and the rate of death of bacteria caused by the three 4-quinolones. Similarly, DNA breakdown did not occur when $\operatorname{recB}$ or $\mathrm{rec} C$ mutants were treated with nalidixic acid despite both mutants being killed by the drug, again suggesting that DNA breakdown is not the cause of bacterial death. Since rec $B$ and $\operatorname{rec} C$ mutants lack exonuclease $\mathrm{V}$, this enzyme may be responsible for the DNA breakdown observed in bacteria treated with 4-quinolones.
\end{abstract}

\section{Introduction}

Previous studies on nalidixic acid have suggested that the degradation of chromosomal DNA might be the cause of bacterial death. This suggestion was based on the observation that when Escherichia coli 15TAU was exposed to nalidixic acid under conditions which resulted in the degradation of bacterial DNA the drug was bactericidal. ${ }^{1}$ Nalidixic acid also causes DNA breakdown in Bacillus subtilis. ${ }^{2}$ Pulse chase experiments indicate that the DNA degradation in $B$. subtilis appears to be initiated at the replication point and proceed sequentially along the chromosome from the "new" DNA to the "old" DNA. ${ }^{3}$ In the present study the degradation of DNA in bacteria exposed to nalidixic acid under conditions in which the drug was either bactericidal or non-bactericidal was investigated. Inhibition of the bactericidal activity of nalidixic acid was achieved by adding the RNA synthesis inhibitor rifampicin or the protein synthesis inhibitor chloramphenicol. ${ }^{4,5}$ The presence of DNA degradation in bacteria exposed to the fluorinated 4-quinolones was also investigated.

DNA breakdown could also be related to the induction of the SOS response by the 4-quinolones. Exonuclease V (exo V) coded for by the $\operatorname{rec} B C$ genes is required for the induction of SOS DNA repair in bacteria treated with nalidixic acid. ${ }^{6}$ The

Received 13 March 1989; revised version accepted 26 July 1989. * Present address: Department of Bacteriology, Medical School, Edinburgh University, Teviot Place, Edinburgh EH8 9AG.

† Correspondence should be sent to Professor J. T. Smith. degradation of DNA in bacteria exposed to nalidixic acid may be due, therefore, to exo $\mathrm{V}$ activity providing the signal by which the SOS response is induced when bacteria are exposed to nalidixic acid. Therefore, DNA degradation in $E$. coli deficient in SOS DNA repair was also studied.

\section{Materials and methods}

\section{Antibacterial agents}

Ciprofloxacin (Bayer), chloramphenicol (Parke Davis) and norfloxacin (Merck Sharpe \& Dohme) were dissolved in sterile distilled water. Nalidixic acid (Sterling Winthrop) was dissolved in $0.5 \mathrm{M} \mathrm{NaOH}(0.02 \mathrm{ml} / \mathrm{mg})$ before being made up to the appropriate concentration in sterile distilled water. Rifampicin (Merrel Dow Pharmaceuticals) was dissolved in dimethyl sulphoxide and then diluted in sterile distilled water.

\section{E. coli strains}

Five strains of $E$. coli were used: KL16 a prototroph; J62-1 pro trp his phe nat ; AB2463 F - thr-1 leu-6 proA2 his4 thi-1 argE3 lacY1 galK2 ara-14 xyl-5 mtl-1 tsx-33 strA31 sup-37 recA13; AB2470, as AB2463 but recB21 instead of recA13; NH4021 met arg thi gal tsx lac+ recC21.

\section{DNA breakdown estimation}

In a previous investigation into the degradation of DNA caused by nalidixic acid, ${ }^{1}$ we found that, after exposure of bacteria whose DNA had been radiolabelled 
to nalidixic acid, the counts of radiolabelled acid-soluble DNA, i.e., nucleotides, were equal to the counts of the cell-free filtrate. ${ }^{1}$ Therefore, the breakdown products of DNA from bacteria exposed to nalidixic acid are present in the medium. This investigation used the presence of radioactivity in the cell-free filtrate of bacteria whose DNA had been radiolabelled to provide an estimate of the amount of DNA degradation occurring in bacteria treated with the 4-quinolones.

A 10-ml volume of Davis and Mingioli (DM) Broth ${ }^{7}$ containing glucose $0.28 \% \mathrm{w} / \mathrm{v}$ was inoculated with a loopful of bacteria taken from a DM agar plate and incubated for $16 \mathrm{~h}$ at $37^{\circ} \mathrm{C}$. The broth was shaken continuously at 150 cycles/min on a Gallenkamp orbital incubator. After incubation, $1 \mathrm{ml}$ of the culture (containing about $10^{8} \mathrm{cfu}$ ) was added to $4 \mathrm{ml}$ of DM broth containing deoxyadenosine $200 \mathrm{mg} / \mathrm{L}$ and methyl ${ }^{3} \mathrm{H}$ or ${ }^{14} \mathrm{C}$ thymidine $(4 \mu \mathrm{Ci} / \mathrm{ml})$ (Amersham International plc) which was then shaken for $4 \mathrm{~h}$ at $37^{\circ} \mathrm{C}$.

Twenty ml of sterile Nutrient Broth (Oxoid No. 2) was added to the culture which was mixed and then centrifuged at $4000 \mathrm{~g}$ for $15 \mathrm{~min}$. The supernate was discarded and the pellet was resuspended in $20 \mathrm{ml}$ of sterile nutrient broth which was again centrifuged for $15 \mathrm{~min}$ at $4000 \mathrm{~g}$. The supernate was discarded and the pellet was resuspended in $10 \mathrm{ml}$ of sterile nutrient broth, which had been prewarmed at $37^{\circ} \mathrm{C}$.

A $4.5-\mathrm{ml}$ volume of the radiolabelled bacteria in nutrient broth was added to an equal volume of each of the sterile nutrient broth preparations containing the various antimicrobial agents, or without antimicrobials (control), all held at $37^{\circ} \mathrm{C}$. At time zero and at $45-\mathrm{min}$ intervals over a period of $3 \mathrm{~h}, 1.5-\mathrm{ml}$ samples were taken from each reaction mixture; $0.5 \mathrm{ml}$ of each sample was added to a scintillation vial containing $2 \mathrm{ml}$ of Aquasol (New England Nuclear). The remaining $1 \mathrm{ml}$ was filtered through a $0.45-\mu \mathrm{m}$ membrane filter (Millipore S.A., Molsheim France) and $0.5 \mathrm{ml}$ of the filtrate from the $1 \mathrm{ml}$ sample was added to a scintillation vial containing $2 \mathrm{ml}$ of Aquasol. The vials were cooled to $4^{\circ} \mathrm{C}$ and the radioactivity was then determined by scintillation counting in a Packard Tri Carb liquid scintillation spectrometer. The radioactivity of the cultures at time zero was about $3000 \mathrm{cpm} / \mathrm{ml}$, compared with background counts of $<50 \mathrm{cpm} / \mathrm{ml}$.

\section{Measurement of rate of kill}

The rate of kill of $E$. coli KL16 by the 4-quinolones in nutrient broth was measured as described by Lewin and Smith. ${ }^{8}$

\section{Results}

When $E$. coli KL16 was exposed to a bactericidal concentration of nalidixic acid $50 \mathrm{mg} / \mathrm{L}$ in nutrient broth, degradation of bacterial DNA occurred (fig. 1). After $3 \mathrm{~h}, 16 \%$ of the ${ }^{3} \mathrm{H}$-labelled thymidine was found in the cell-free filtrate of bacteria exposed to nalidixic acid compared with $7 \%$ in the cell-free filtrate of untreated control bacteria (table I). Similar results were obtained with ${ }^{14} \mathrm{C}$ thymidine (fig. 1). After $3 \mathrm{~h}, 17 \%$ of the ${ }^{14} \mathrm{C}$-labelled thymidine was present in the cell-free filtrate of $E$. coli KL16 exposed to nalidixic acid $50 \mathrm{mg} / \mathrm{L}$, compared with $6.5 \%$ in the cell-free filtrate of the untreated control (table I). In all of the subsequent experiments only ${ }^{3} \mathrm{H}$ thymidine was used.

The amount of DNA breakdown under conditions in which nalidixic acid was not bactericidal
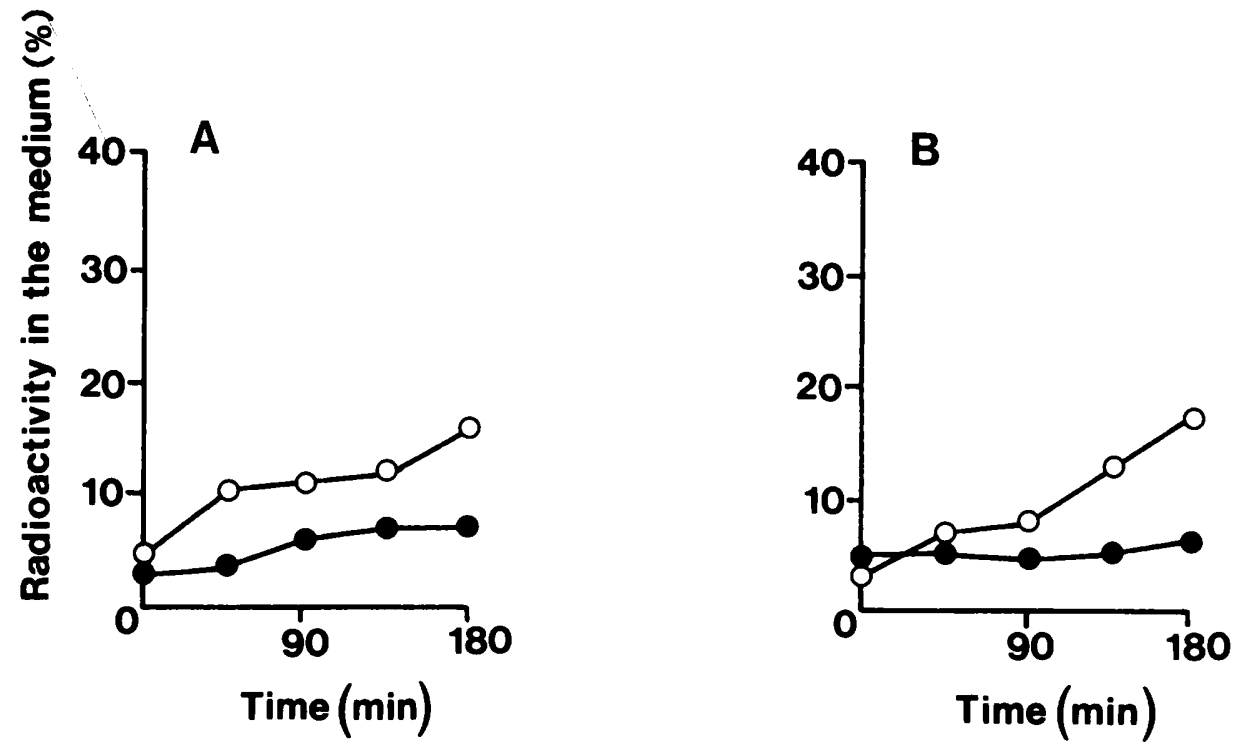

Fig. 1. Release of ${ }^{3} \mathrm{H}$ thymidine (A) and ${ }^{14} \mathrm{C}$ thymidine (B) from $E$. coli $\mathrm{KL} 16$ treated with nalidixic acid $50 \mathrm{mg} / \mathrm{L}$. (O-O) and control cultures $(-0)$. 
Table I. Nucleotide release from $E$. coli KL16 after $3 \mathrm{~h}$

\begin{tabular}{lc|ccc}
\hline & $\begin{array}{c}\text { Concentration } \\
(\mathrm{mg} / \mathrm{L}):\end{array}$ & $\begin{array}{c}\text { Percentage of radioactivity in } \\
\text { cell-free filtrate of treated bac- } \\
\text { teria }\end{array}$ & $\begin{array}{c}\text { Percentage of radioactivity in } \\
\text { cell-free filtrate of untreated } \\
\text { (control) bacteria }\end{array}$ & $\begin{array}{c}\text { Difference } \\
\text { (treated - control) }\end{array}$ \\
\hline nal & 50 & 16 & $7 \cdot 0$ & $9 \cdot 0$ \\
nal + rif & $50+160$ & $17 \cdot 0$ & $5 \cdot 1$ & $11 \cdot 9$ \\
nal $+\mathrm{cm}$ & $50+20$ & $12 \cdot 7$ & $4 \cdot 8$ & $7 \cdot 9$ \\
rif & 160 & $4 \cdot 7$ & $4 \cdot 5$ & $0 \cdot 2$ \\
cm & 20 & $5 \cdot 6$ & $7 \cdot 0$ & $-1 \cdot 4$ \\
nor & $1 \cdot 5$ & $30 \cdot 1$ & $6 \cdot 1$ & $24 \cdot 0$ \\
cip & $0 \cdot 02$ & $38 \cdot 2$ & $4 \cdot 1$ & $34 \cdot 1$ \\
cip & $0 \cdot 15$ & $20 \cdot 0$ & $5 \cdot 6$ & $14 \cdot 4$ \\
cip & 1 & $28 \cdot 5$ & $5 \cdot 6$ & $22 \cdot 9$ \\
cip & 5 & $33 \cdot 2$ & $4 \cdot 5$ & 28.7 \\
\hline
\end{tabular}

nal $=$ Nalidixic acid, $\mathrm{cm}=$ chloramphenicol, rif $=$ rifampicin, nor $=$ norfloxacin, cip $=$ ciprofloxacin.

was determined. The RNA synthesis inhibitor rifampicin or the protein synthesis inhibitor chloramphenicol abolished the bactericidal activity of nalidixic acid in nutrient broth (table II). The addition of rifampicin $160 \mathrm{mg} / \mathrm{L}$ to nalidixic acid $50 \mathrm{mg} / \mathrm{L}$ did not reduce DNA degradation in $E$. coli KL16 (fig. 2). After $3 \mathrm{~h}, 17 \%$ of the radioactivity had been released into the nutrient broth which was similar to the result obtained with $E$. coli KL16 exposed to nalidixic acid $50 \mathrm{mg} / \mathrm{L}$ alone (fig. 1 and table I). The degradation of bacterial DNA also occurred in $E$. coli KL16 exposed to chloramphenicol $20 \mathrm{mg} / \mathrm{L}$ and nalidixic acid $50 \mathrm{mg} / \mathrm{L}$ (fig. 2). After $3 \mathrm{~h}, 12.7 \%$ of the radioactivity was present in the cell-free filtrate, a decrease of about $25 \%$ compared to the cell-free filtrate of bacteria exposed to nalidixic acid $50 \mathrm{mg} / \mathrm{L}$ alone, but more than double the $4.8 \%$ value in the untreated control (table I). Therefore, DNA degradation appears to occur in bacteria exposed to nalidixic acid whether or not the bacteria are dying.

The release of nucleotides into the medium may occur when $E$. coli $\mathrm{KL} 16$ is exposed to either chloramphenicol or rifampicin alone. However, when $E$. coli KL16 was exposed to either rifampicin $160 \mathrm{mg} / \mathrm{L}$ or chloramphenicol $20 \mathrm{mg} / \mathrm{L}$ no significant increase in ${ }^{3} \mathrm{H}$-labelled thymidine was found in the cell-free filtrate compared with untreated controls (fig. 2 and table I). Therefore, these two antibacterials alone do not cause any detectable degradation of $E$. coli KL16 chromosomal DNA.

DNA degradation in bacteria exposed to the

Table II. Relationship between DNA degradation and bactericidal activity of 4-quinolones against $E$. coli KL16

\begin{tabular}{|c|c|c|c|}
\hline Agent & $\begin{array}{c}\text { Concentration } \\
(\mathrm{mg} / \mathrm{L})\end{array}$ & $\begin{array}{l}\text { Difference in percentage of } \\
\text { radioactivity released from } \\
\text { treated and untreated } \\
\text { (control) bacteria }\end{array}$ & $\begin{array}{l}\text { Percentage } \\
\text { survival } \\
\text { after } 3 \mathrm{~h}\end{array}$ \\
\hline nal & 50 & 9.0 & 0.3 \\
\hline cip & 0.004 & $1 \cdot 6$ & $100 \cdot 00$ \\
\hline cip & 0.02 & $34 \cdot 1$ & 0.25 \\
\hline cip & $0 \cdot 15$ & 14.4 & 0.03 \\
\hline cip & 1 & 22.9 & $0 \cdot 1$ \\
\hline cip & 5 & $28 \cdot 7$ & $0 \cdot 15$ \\
\hline nor & 1.5 & $24 \cdot 0$ & 0.03 \\
\hline rif & 160 & 0.2 & 98 \\
\hline $\mathrm{cm}$ & 20 & $-1 \cdot 4$ & 104 \\
\hline $\mathrm{nal}+$ rif & $50+160$ & 7.9 & 89 \\
\hline $\mathrm{nal}+\mathrm{cm}$ & $50+20$ & 11.9 & 92 \\
\hline
\end{tabular}

See footnote to table I for abbreviations. 

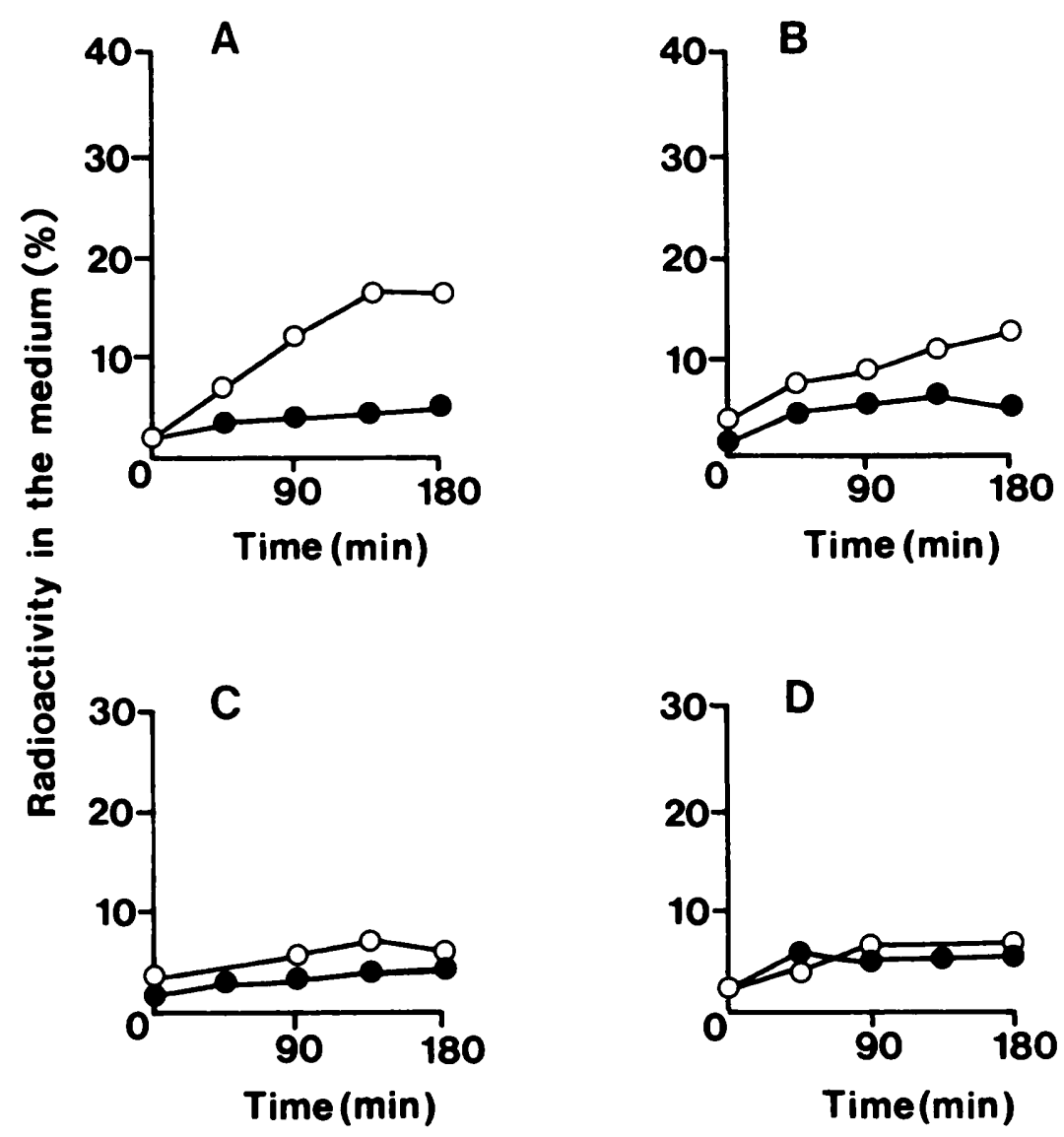

Fig. 2. Release of ${ }^{3} \mathrm{H}$ thymidine from $E$. coli $\mathrm{KL} 16$ treated with: (A) nalidixic acid $50 \mathrm{mg} / \mathrm{L}+$ rifampicin $160 \mathrm{mg} / \mathrm{L}$; (B) nalidixic acid $50 \mathrm{mg} / \mathrm{L}$ + chloramphenicol $20 \mathrm{mg} / \mathrm{L}$; (C) rifampicin $160 \mathrm{mg} / \mathrm{L}$; (D) chloramphenicol $20 \mathrm{mg} / \mathrm{L}(\mathrm{O}-\mathrm{O}$, treated cultures; , untreated control cultures).

modern fluorinated 4-quinolones was determined. $E$. coli KL16 displayed a biphasic response with the bactericidal activity of the drugs increasing up to an optimum bactericidal concentration. Beyond this concentration the drugs became increasingly less bactericidal. Therefore, degradation of DNA in $E$. coli $\mathrm{KL} 16$ exposed to ciprofloxacin and norfloxacin was determined at their optimal bactericidal concentration. It was assumed that DNA degradation was greatest at the concentration at which the 4-quinolones were most lethal. When $E$. coli $\mathrm{KL} 16$ was exposed to norfloxacin $1.5 \mathrm{mg} / \mathrm{L}$, $30 \%$ of the total radioactivity was found in the cellfree filtrate after $3 \mathrm{~h}$ (tables I and II). Conversely, the optimal bactericidal concentration of ciprofloxacin, $0.15 \mathrm{mg} / \mathrm{L}$, resulted in only $20 \%$ of the radioactivity appearing in the cell-free filtrate (tables I and II) when it was used against $E$. coli KL16. Therefore, it appears that DNA breakdown is associated with $E$. coli treated with any 4- quinolone. However, the amount of kill obtained by exposing $E$. coli KL16 to the optimal bactericidal concentration of either norfloxacin or ciprofloxacin was the same (table II), but the level of nucleotide released by the bacteria was much higher with norfloxacin than with ciprofloxacin.

$E$. coli KL16 was exposed to various concentrations of ciprofloxacin above and below the optimal bactericidal concentration. In $E$. coli KL16 exposed to ciprofloxacin $0.02 \mathrm{mg} / \mathrm{L}, 38.2 \%$ of the total radioactivity was found in the medium after $3 \mathrm{~h}$, compared with $4.1 \%$ in the medium from untreated bacteria (table I). In $E$. coli $\mathrm{KL} 16$, after exposure for $3 \mathrm{~h}$ to ciprofloxacin $1 \mathrm{mg} / \mathrm{L}, 28.5 \%$ of the radioactivity was detected in the cell-free filtrate, whereas $33.2 \%$ of the radioactivity was detected in the cell-free filtrate after exposure to ciprofloxacin $5 \mathrm{mg} / \mathrm{L}$ for $3 \mathrm{~h}$ (table $\mathrm{I}$ ). With ciprofloxacin, concentrations of $0.02,1$ and $5 \mathrm{mg} / \mathrm{L}$ were all less bactericidal than $0.15 \mathrm{mg} / \mathrm{L}$ (table II), yet degra- 
dation of bacterial DNA was higher in all three cases. No direct correlation between the degree of bactericidal activity and the amount of DNA breakdown caused by ciprofloxacin was observed.

$E$. coli $\mathrm{J} 62-1$ is biochemically resistant to 4quinolone; MICs for nalidixic acid and ciprofloxacin are $500 \mathrm{mg} / \mathrm{L}$ and $0.15 \mathrm{mg} / \mathrm{L}$ respectively (compared to $3 \mathrm{mg} / \mathrm{L}$ and $0.004 \mathrm{mg} / \mathrm{L}$ for $E$. coli $\mathrm{KL} 16$ ). When $E$. coli J62-1 was exposed to nalidixic acid $50 \mathrm{mg} / \mathrm{L}$, no increase in the percentage of total radioactivity was detected in the cell-free filtrate compared with that from untreated bacteria (table III). This is in contrast to the DNA degradation that occurred when $E$. coli KL16 was exposed to the same concentration of the antibacterial (table I). Similarly, when $E$. coli J62-1 was exposed to ciprofloxacin $0.02 \mathrm{mg} / \mathrm{L}$, DNA degradation was not detected (table III). Again this contrasts with the degradation of DNA that occurred when $E$. coli KL16 was exposed to the same concentration of the drug (table I). Conversely, when $E$. coli J62-1 was exposed to ciprofloxacin $2 \mathrm{mg} / \mathrm{L}$, a concentration to which it is sensitive, degradation of bacterial DNA was detected (table III). Therefore, the degradation of bacterial DNA in bacteria exposed to the 4-quinolones only appears to occur at concentrations above the MIC.

$\operatorname{Rec} A 13, \operatorname{recB} 21$ and $\operatorname{rec} C 21$ mutants of $E$. coli

Table III. Nucleotide release from $E$. coli J62-1 after 3 h

\begin{tabular}{|c|c|c|c|c|}
\hline Agent & $\begin{array}{l}\text { Concen- } \\
\text { tration } \\
(\mathrm{mg} / \mathrm{L})\end{array}$ & $\begin{array}{l}\text { Percentage of } \\
\text { radioactivity } \\
\text { in cell-free fil- } \\
\text { trate of treated ( } \\
\text { bacteria }\end{array}$ & $\begin{array}{l}\text { Percentage of } \\
\text { radioactivity } \\
\text { in cell-free } \\
\text { filtrate of } \\
\text { untreated } \\
\text { (control) bac- } \\
\text { teria }\end{array}$ & $\begin{array}{c}\text { Differ- } \\
\text { ence } \\
\text { (treated- } \\
\text { control) }\end{array}$ \\
\hline $\begin{array}{l}\text { nal } \\
\text { cip } \\
\text { cip }\end{array}$ & $\begin{array}{l}50 \\
0.02 \\
2\end{array}$ & $\begin{array}{r}2 \cdot 5 \\
3.5 \\
15 \cdot 9\end{array}$ & $\begin{array}{l}2 \cdot 6 \\
3 \cdot 6 \\
2 \cdot 7\end{array}$ & $\begin{array}{r}-0.1 \\
-0.1 \\
13.2\end{array}$ \\
\hline
\end{tabular}

See footnote to table I for abbreviations. lack the SOS response. The $\operatorname{recB} 21$ and $\operatorname{rec} C 21$ mutants lack exo $\mathrm{V}$ activity whereas the $\operatorname{rec} A 13$ mutant is unable to inactivate the lex $A$ repressor. In both the recB21 and recC21 mutants, no significant increase was found in the radioactivity of the cell-free filtrate of bacteria exposed to nalidixic acid $50 \mathrm{mg} / \mathrm{L}$, as compared with the cellfree filtrate of untreated bacteria, after $3 \mathrm{~h}$ (table IV). However, about $19 \%$ of the total radioactivity of the control cultures was found in the cell-free filtrate after $3 \mathrm{~h}$ which was significantly higher than the levels found in the filtrate of untreated $E$. coli KL16 or J62-1 (tables I and III). Conversely, when a recA13 mutant, which possesses a functional exo $\mathrm{V}$ but is SOS deficient, was exposed to nalidixic acid $50 \mathrm{mg} / \mathrm{L}$, the radioactivity in the cell-free filtrate was significantly higher than from untreated bacteria although the level in the untreated control was very high (table IV). Therefore, it appears that the DNA degradation occurring in bacteria treated with 4-quinolones may require the activity of exo $\mathrm{V}$, which is also essential for the induction of the SOS response by nalidixic acid.

\section{Discussion}

Degradation of DNA in bacteria exposed to nalidixic acid occurred even under conditions in which nalidixic acid was not bactericidal. Furthermore, no degradation of bacterial DNA was detected in $\operatorname{rec} B$ or $\operatorname{rec} C$ mutants which are even more sensitive to nalidixic acid than wild type bacteria. $^{9,10}$ Hence DNA breakdown does not appear to contribute to the lethal action of nalidixic acid, as had been suggested previously. ${ }^{1}$ Cook et $a l .{ }^{1}$ concluded that DNA breakdown occurred only under conditions in which nalidixic acid was lethal, because the addition of chloramphenicol to nalidixic acid reduced the amount of nucleotides released from $E$. coli $15 \mathrm{TAU}$, compared to bacteria exposed to the 4-quinolone alone. Nevertheless, in their experiments the radioactivity released in the presence of chloramphenicol and nalidixic acid was

Table IV. Nucleotide release after $3 \mathrm{~h}$ from various $E$. coli strains exposed to nalidixic acid $50 \mathrm{mg} / \mathrm{L}$

\begin{tabular}{lccr}
\hline $\begin{array}{l}\text { E. coli } \\
\text { strain }\end{array}$ & $\begin{array}{c}\text { Percentage of radioactivity in } \\
\text { cell-free filtrate of treated bac- } \\
\text { teria }\end{array}$ & $\begin{array}{c}\text { Percentage of radioactivity in cell- } \\
\text { free filtrate of untreated (control) } \\
\text { bacteria }\end{array}$ & $\begin{array}{c}\text { Difference } \\
\text { (treated- } \\
\text { control) }\end{array}$ \\
\hline recB21 & 18.9 & $19 \cdot 3$ & -0.4 \\
$r e c C 21$ & $18 \cdot 8$ & 18.5 & $0 \cdot 3$ \\
rec $A 13$ & $47 \cdot 4$ & 32.4 & $15 \cdot 0$ \\
\hline
\end{tabular}


still significantly higher than that from untreated bacteria and hence do not differ from the results obtained in this investigation.

DNA degradation was also detected when E. coli was exposed to ciprofloxacin or norfloxacin but no correlation could be found between the degree of bactericidal activity of these two drugs and the amount of DNA degradation. Therefore, DNA degradation does not appear to contribute to the lethal action of the fluorinated 4-quinolones. However, as it only occurred at concentrations above the MIC, rather than being dependent on a specific concentration of the antibacterial, DNA degradation appears to be associated with the antibacterial activity of the 4-quinolones. This association may be due to a requirement for degradation of bacterial DNA for the SOS response to be induced by the 4quinolones. The degradation of DNA in $E$. coli exposed to nalidixic acid appeared to require the activity of exo $\mathrm{V}$ (coded by the $\operatorname{rec} B C$ genes) which is essential for the induction of the SOS response by nalidixic acid. ${ }^{6}$ The activity of exo $\mathrm{V}$ might be required to provide the free nucleotides required for SOS induction. ${ }^{6}$ It may seem that the results implicating exo $\mathrm{V}$ in the breakdown of DNA in bacteria exposed to nalidixic acid should be regarded with caution because high levels of DNA breakdown were observed in cultures of $\operatorname{rec} A, \operatorname{rec} B$ or rec $C$ mutants that were not treated with the drug. However, because nalidixic acid-induced DNA breakdown was significantly higher than back-

\section{REFERENCES}

1. Cook T M, Dietz W H, Goss W A. Mechanism of action of nalidixic acid on Escherichia coli: IV Effects on the stability of cellular constituents. $J$ Bacteriol 1966; 91 : 774-779.

2. Cook T M, Brown K G, Boyle J V, Goss W A. Bactericidal action of nalidixic acid on Bacillus subtilis 168. J Bacteriol 1966; 92 : 1510-1514.

3. Ramareddy G, Reiter $H$. Specific loss of newly replicated deoxyribonucleic acid in nalidixic acid-treated Bacillus subtilis. J Bacteriol 1969; 100: 724-729.

4. Smith J T. Awakening the slumbering potential of the 4quinolone antibacterials. Pharm J 1984; 233 : 299-305.

5. Smith J T, Lewin C S. Chemistry and mechanism of action of the quinolone antibacterials. In: Andriole V (ed) The quinolones. London, Academic Press. 1988: 2382.

6. Walker G C. Mutagenesis and inducible responses to deoxyribonucleic acid damage in Escherichia coli. Microbiol Rev 1984; 48: 60-93.

7. Davis B C, Mingioli E S. Mutants of Escherichia coli requiring methionine or vitamin B12.J Bacteriol 1950; 60: $17-28$.

8. Lewin CS, Smith J T. Bactericidal mechanisms of ofloxacin. $J$ Antimicrob Chemother 1988 ; 22 suppl C: 1-8.

9. McDaniel L S, Rogers L H, Hill W E. Survival of ground in a $\operatorname{rec} A$ mutant (which possesses a functional exo V), but not in the $\operatorname{rec} B$ or $\operatorname{rec} C$ mutants the conclusions drawn from experiments with these mutants appear to be valid.

An alternative hypothesis for the DNA degradation caused by the 4-quinolones is that it may be due to bacterial lysis following exposure to lethal concentrations of antibacterial. However, this investigation found that DNA degradation still occurred in the presence of chloramphenicol or rifampicin which prevent the bactericidal activity of nalidixic acid. ${ }^{4,11}$ Hence, this hypothesis seems unlikely despite the well documented effects of 4quinolones on the bacterial membrane. ${ }^{12}$

In conclusion, although DNA degradation occurs in bacteria exposed to 4-quinolones it does not appear to contribute to the lethal action of these drugs but may play a role in the induction of the SOS response. If this is indeed the case, it is interesting to note that the SOS response does not seem to contribute to the lethality of the 4quinolones ${ }^{10}$ as has been previously suggested. ${ }^{13}$ Furthermore, the SOS response, despite being induced by the 4-quinolones, ${ }^{14,15}$ does not appear to be involved in repairing the damage to the bacterial chromosome caused by the drug ${ }^{10}$ as has also been suggested. ${ }^{16}$ Hence, neither DNA breakdown nor the SOS DNA repair pathway seem to be involved in the bacterial response to the 4-quinolone antibacterials.

recombination-deficient mutants of Escherichia coli during incubation with nalidixic acid. $J$ Bacteriol 1978 ; 134: 1195-1198.

10. Lewin C S, Howard B M A, Ratcliffe N T, Smith J T. 4quinolones and the SOS response. $J$ Med Microbiol $1989 ; 29: 139-144$.

11. Dietz W H, Cook T M, Goss W A. Mechanism of action of nalidixic acid on Escherichia coli: III conditions required for lethality. $J$ Bacteriol 1966; 91 : 768-773.

12. Dougherty T J, Saukkonen J J. Membrane permeability changes associated with DNA gyrase inhibitors in Escherichia coli. Antimicrob Agents Chemother 1985; 28: 200-206.

13. Chow R T, Dougherty T J, Fraimow H S, Bellin E Y, Miller $M$ H. Association between early inhibition of DNA synthesis and the MICs and MBCs of carboxyquinolone antimicrobial agents for wild-type and mutant ( $g y r A$ $n f x B$ (ompF) acrA) Escherichia coli K12. Antimicrob Agents Chemother 1988; 32: 1113-1118.

14. Piddock $L \mathbf{J} \mathrm{V}, \mathrm{W}$ ise $\mathrm{R}$. Induction of the $S O S$ response in Escherichia coli by 4-quinolone antimicrobial agents. FEMS Microbiol Lett 1987; 41: 289-294.

15. Phillips I, Culebras E, Moreno F, Baquero P. Induction of the SOS response by new 4-quinolones. $J$ Antimicrob Chemother 1987; 20: 631-638.

16. Drlica K. Biology of bacterial deoxyribonucleic acid topoisomerases. Microbiol Rev 1984; 48: 273-289. 